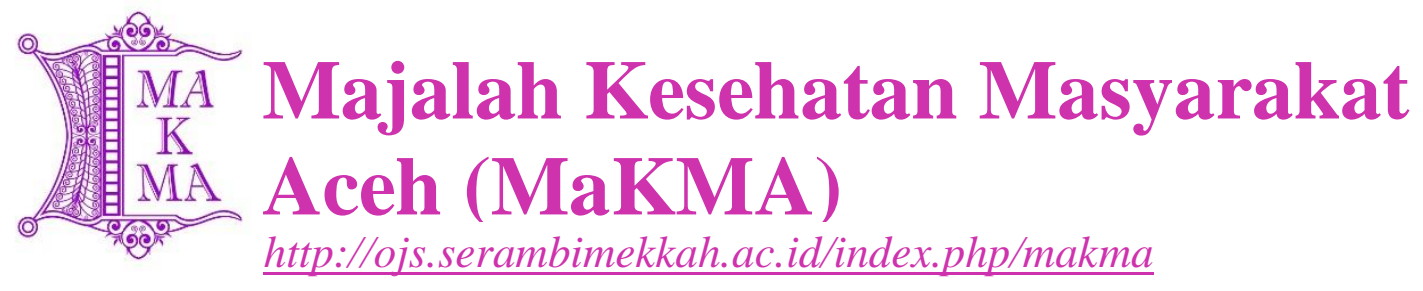

\title{
FAKTOR YANG BERHUBUNGAN DENGAN RISIKO TERJADINYA ULKUS DIABETIKA PADA PASIEN DIABETES MELLITUS (Studi di Poliklinik Endokrin Rumah Sakit Umum Daerah dr. Zainoel Abidin Banda Aceh)
}

\author{
Khairunnisak $^{\bowtie}$ \\ Prodi D-III Keperawatan Meulaboh Poltekkes Kemenkes Aceh
}

${ }^{\square}$ Alamat Korespondensi: Prodi D-III Keperawatan Meulaboh Poltekkes Kemenkes Aceh / Email: syifaazzaliaazzahra@gmail.com

\begin{abstract}
ABSTRAK
Diabetes Mellitus terdiri dari umur, lama Diabetes Mellitus (DM), Neuropati, Obesitas, Hipertensi, kebiasaan merokok, ketidakpatuhan diet DM, kurangnya aktivitas fisik, pengobatan tidak tertentu, perawatan kaki tidak teratur dan penggunaan alas kaki tidak tepat. Jumlah pasien Diabetes Mellitus yang berobat dan rawat jalan dari bulan Januari sampai dengan maret 2018 di Poliklinik Endokrin yang mengalami ulkus diabetika sebanyak $113(8,25 \%)$. Tujuan penelitian untuk menganalisis faktor risiko terjadinya ulkus diabetika pada pasien Diabetika Mellitus di Poliklinik Endokrin Rumah Sakit Umum Daerah dr. Zainoel Abidin Banda Aceh 2013, yang meliputi faktor umur, lama Diabetes Mellitus, Kepatuhan diet DM dan Keteraturan pengobatan. Desain penelitian menggunakan survey analitik, dengan desain cros-sectional. Jumlah sampel 93 orang. Menggunakan teknik accidental sampling. Pengumpulan data menggunakan kuesioner. Hasil penelitian menemukan bahwa risiko terjadinya ulkus pada pasien DM berhubungan dengan faktor umur p-value $0.000(\mathrm{p}<0.05)$, faktor lama DM p-value $0.000(\mathrm{p}<0.05)$, faktor kepatuhan diet Diabetes Mellitus p-value $0.001(\mathrm{p}<0.05)$, dan faktor Keteraturan pengobatan $\mathrm{p}$-value 0.002 $(\mathrm{p}<0.05)$. Penelitian ini memberikan saran kepada manajerial Poliklinik Endokrin RSUD Dr. Zainoel Abidin Banda Aceh untuk memberikan konseling tentang risiko terjadinya Ulkus Diabetikum pada pasien DM.
\end{abstract}

Kata Kunci : Risiko, Ulkus Diabetika, Diabetes Mellitus.

Riwayat Artikel 
FACTORS RELATED TO THE RISK OF THE DIABETIC ULKUS IN DIABETABEL MELLITUS PATIENTS (Study in the Endocrine Polyclinic of the Regional General Hospital of dr. Zainoel Abidin Banda Aceh)

\begin{abstract}
Diabetes Mellitus consists of; age, duration of Diabetes Mellitus (DM), Neuropathy, Obesity, Hypertension, smoking habits, DM dietary disobedience, lack of physical activity, non-specific treatment, irregular foot care and improper use of footwear. The number of patients with diabetes mellitus treated and outpatient from January to March 2018 in the Endocrine Polyclinic who had diabetic ulcers was $113(8.25 \%)$. The aim of the study was to analyze the risk factors for diabetic ulcers in diabetic patients with mellitus in the Endocrine Polyclinic of the Regional General Hospital, Dr. Zainoel Abidin Banda Aceh 2013, which included factors such as age, duration of diabetes mellitus, compliance with DM diets and regularity of treatment. The study design used analytical surveys, with a cross-sectional design. Total sample is 93 people. Using accidental sampling technique. Data collection using a questionnaire. The results of the study found that the risk of ulcers in DM patients was related to the age factor p-value $0.000(\mathrm{p}<0.05)$, the old DM factor $\mathrm{p}$-value $0.000(\mathrm{p}<0.05)$, the Diabetes Mellitus diet compliance factor $\mathrm{p}$-value 0.001 ( $\mathrm{p}$ $<0.05$ ), and treatment regularity factor $\mathrm{p}$-value $0.002(\mathrm{p}<0.05)$. This study gave advice to managenial Endocrine Polyclinic of dr.RSUD Zainoel Abidin Banda Aceh to provide counselling about the risk of Diabetic Ulcers in DM patient.
\end{abstract}

Keywords: Risk, Diabetic Ulcer, Diabetes Mellitus. 


\section{PENDAHULUAN}

Sistem Kesehatan Nasional menyatakan bahwa segala upaya dalam pembangunan kesehatan di Indonesia diarahkan untuk mencapai derajat kesehatan yang lebih tinggi yang memungkinkan orang hidup lebih produktif baik sosial maupun ekonomi. Dengan meningkatnya status sosial dan ekonomi, pelayanan kesehatan masyarakat, perubahan gaya hidup, bertambahnya umur harapan hidup, maka di Indonesia mengalami pergeseran pola penyakit dari penyakit menular menjadi penyakit tidak menular, hal ini dikenal dengan transisi epidemiologi. Kecenderungan meningkatnya prevalensi penyakit tidak menular salah satunya adalah Diabetes Mellitus. ${ }^{[1]}$

Diabetes Mllitus (DM) merupakan suatu penyakit menahun yang ditandai oleh kadar glukosa darah melebihi normal dan gangguan metabolisme karbohidrat, lemak dan protein yang disebabkan oleh kekurangan hormon insulin secara relatif maupun absolut. Bila hal ini dibiarkan tidak terkendali dapat terjadi komplikasi metabolik akut maupun komplikasi vaskuler jangka panjang, baik mikroangiopati maupun makroangiopati. ${ }^{[2]}$

Prevalensi DM di dunia terus meningkat jumlah penderita diabetes di dunia tahun 2007 meningkat menjadi 175 juta orang dan tahun 2010 sudah mencapai sekitar 197 juta jiwa dengan kematian sekitar 3,2 juta orang pertahun. WHO memprediksikan akan ada 366 juta pasien DM pada tahun 2030. Penyumbang terbesar angka tdi adalah negara-negara berkembang, yang mengalami kenaikan penderita diabetes sekitar $150 \%$, yang mengkhawatirkan sekitar 505 penderita diabetes tidak menyadari kondisi mereka, dan di beberapa negara jumlahnya mencapai $80 \%{ }^{[3]}$

Menurut data WHO, Indonesia menempati urutan ke - 4 terbesar dalam jumlah penderita Diabetes Mellitus di dunia. Pada tahun 2000 yang lalu saja, terdapat sekitar 5,6 juta penduduk Indonesia yang mengidap diabetes. Namun, pada tahun 2006 diperkirakan jumlah penderita diabetes di Indonesia meningkat tajam menjadi 14 juta orang, dimana baru 505 yang sadar mengidapnya dan di antara mereka baru sekitar $30 \%$ yang datang berobat teratur. [1]

Komplikasi diabetes dapat terjadi pada semua tipe DM, baik pada tipe I maupun tipe II. Di beberapa negara, diabetes merupakan penyebab utama ulkus dan amputasi di luar trauma kecelakaan. Ulserasi ganggren dan amputasi sangat bervariasi pada setiap negara karena perbedaan karakteristik seperti halnya gaya hidup, faktor sosial dan ekonomi. Risiko dari amputasi tungkai bawah adalah 15-46 kali lebih tinggi pada penyakit diabetes dibanding orang yang tidak mempunyai diabetes mellitus. ${ }^{[4]}$

Faktor risiko terjadi ulkus diabetika pada penderita Diabetes Mellitus terdiri dari; umur, lama Diabetes Mellitus (DM), Neuropati, Obesitas, Hipertensi, kebiasaan merokok, ketidakpatuhan diet DM, kurangnya aktivitas fisik, pengobatan tidak teratur, perawatan kaki tidak teratur dan penggunaaan alas kaki tidak tepat. ${ }^{[5]}$

Penelitian oleh David bahwa ketidakpatuhan diet merupakan faktor risiko terjadinya ulkus diabetika. Penelitian oleh Rocher, Calle, dan Gayle bahwa kurang aktivitas fisik, perawatan kaki tidak teratur, dan penggunaan alas kaki tidak tepat merupakan faktor risiko terjadinya ulkus diabetika. Penelitian 
oleh Robert bahwa umur $\geq 60$ tahun dan hipertensi merupakan faktor risiko terjadinya ulkus diabetika.

Masalah ulkus diabetika merupakan masalah serius di Rumah Sakit Umum Daereah dr. Zainoel Abidin Banda Aceh. Dari 1325 penderita Diabetes Mellitus yang berobat dab rawat jalan dari bulan Januari sampai dengan Maret 2018 di Poliklinik Endokrin yang mengalami ulkus diabetika sebanyak 113 atau sekitar $(8,25 \%)$ dan dari hasil wawancara dengan beberapa responden peneliti mendapatkan informasi bahwa, ulkus yang terjadi pada pasien Diabetes Mellitus karena tidak teraturnya pengobatan dan luka yang dialami akibat cedera tusukan di kaki atau goresan benda tajam. ${ }^{[6]}$

Berdasarkan latar belakang tersebut di atas, maka peneliti berkeinginan untuk melakukan penelitian tentang "Faktor Yang Berhubungan Dengan Risiko Terjadinya

\section{HASIL}

Hasil penelitian rengan
menggunakan analisis univariat
diperoleh bahwa dari 93 responden pada
karakteristik Jenis Kelamin, Pendidikan
dan Pekerjaan di Poliklinik Endokrin BLUD dr. Zainoel Abidin Tahun 2018, diketahui bahwa sebagian besar responden berjenis kelamin perempuan yaitu sebanyak 51 responden $(54,8 \%)$, pendidikan responden mayoritasnya berpendidikan SMA yaitu sebanyak 34 responden $\quad(36,6 \%)$ sedangkan pekerjaan responden mayoritasnya bekerja sebagai swasta yaitu sebanyak 58 responden $(62,4 \%)$. Pada Variabel Status Ulkus Diabetikum menggambarkan bahwa mayoritas responden berstatus tidak ulkus yaitu sebanyak 63 responden $(67,7 \%)$. Sedangkan pada variabel status umur menggambarkan bahwa mayoritas
Ulkus Diabetika Pada Pasien Diabetes Mellitus di Poliklinik Endokrin Rumah Sakit Umum Daerah dr. Zainoel Abidin Banda Aceh 2018".

\section{METODE}

Penelitian ini menggunakan jenis yang terdiri dari penelitian survey analitik, Adapun desain penelitian yang digunakan adalah cros-sectional. Alat pengumpulan data menggunakan kuesioner meliputi data demografi responden, faktor risiko terjadinya ulkus diabetika dan klasifikasi ulkus diabetika pada pasien Diabetes Mellitus.

Pengumpulan data dilakukan pada tanggal 03 sampai 5 September 2018 terhadap 93 orang responden dengan menggunakan teknik Accidental Sampling. Analisis data dan pengolahan data menggunakan komputerisasi.

responden berumur $\leq 60$ tahun yaitu sebanyak 62 responden $(66,7 \%)$ [Tabel.1].

Variabel faktor lama diabetes millitus diketahui bahwa lamanya responden mengalami Diabetes Mellitus mayoritas $\leq 10$ tahun yaitu sebanyak 85 responden (91,4\%). Pada variabel kepatuhan diet DM diperoleh bahwa mayoritas responden tidak patuh dalam diet Diabetes Mellitus yaitu sebanyak 53 responden $(57 \%)$, sedangkan pada varibale keteraturan minum obat diketahui bahwa umumnya responden tidak teratur dalam pengobatan Diabetes Mellitus yaitu sebanyak 51 responden $(54,8 \%)$ [Tabel.1].

Berdasarkan analisis univariat dengan menggunakan dengan uji chisquare, diperoleh hasil bahwa adanya hubungan umur dengan risiko terjadinya ulkus diabetika $\mathrm{p}$ value $=0.000(\mathrm{p}<0.05)$, 
dengan nilai OR : 5.769 (2.227-14.944). Terdapat hubungan kepatuhan diet DM dengan risiko terjadinya ulkus diabetika $\mathrm{p}$ value $=0.001(\mathrm{p}<0.05)$, dengan nilai $\mathrm{OR}$ : 6.250 (2.120-18.426), dan ada

\section{PEMBAHASAN}

Hasil analisis diperoleh nilai OR : $\quad 5.769$ (2.227-14.944), artinya responden yang berusia diatas $\geq 60$ tahun mempunyai peluang sebesar 5,8 kali untuk risiko terjadinya ulkus diabetika dibandingkan dengan responden yang berusia $<60$ tahun.

Hasil penelitian ini sesuai dengan teori, bahwa umur $\geq 60$ tahun berkaitan dengan terjadinya ulkus diabetika karena pada usia tua, fungsi tubuh secara fisiologis menurun karena proses aging terjadi penurunan sekresi atau resistensi insulin sehingga kemampuan fungsi tubuh terhadap pengendalian glukosa darah yang tinggi kurang optimal. Penelitian serupa di Amerika Serikat menunjukkan bahwa dari tahun 19961997 pada lansia umur > 60 tahun, didapatkan hanya $12 \%$ saja pada usia tua dengan DM yang kadar glukosa darah terkendali, 8\% kadar kolesterol normal, hipertensi $40 \%$, dan 50\% mengalami gangguan pada aterosklerosis, makroangiopati yang faktor-faktor tersebut akan mempengaruhi penurunan sirkulasi darah salah satunya pembuluh darah besar atau sedang di tungkai yang lebih mudah terjadi ulkus diabetika. ${ }^{[7]}$

Hasil penelitian Boyko di USA pada 749 penderita Diabetes Mellitus dengan hasil bahwa lama menderita DM $\geq 10$ tahun merupakan faktor risiko terjadinya ulkus diabetika dengan RRnya sebesar (95\% CI : 1,2 - 6,9). Hasil penelitian lain menyatakan bahwa ulkus diabetika terutama terjadi pada penderita Diabetes Mellitus yang telah menderita 10 tahun atau lebih, apabila kadar glukosa darah tidak terkendali, maka akan muncul komplikasi yang hubungan keteraturan pengobatan dengan risiko terjadinya ulkus diabetika $\mathrm{p}$ value $=0.002(\mathrm{p}<0.05)$, dengan nilai $\mathrm{OR}$ : 5.333 (1.915 - 14.855) [Tabel.2].

berhubungan dengan vaskuler sehingga mengalami makroangiopatimikroangiopati yang akan terjadi vaskulopati dan neuropati yang mengakibatkan menurunnya sirkulasi darah dan adanya robekan/luka pada kaki penderita diabetik yang sering tidak dirasakan. ${ }^{[8]}$

Hasil analisis diperoleh nilai OR : 6.250 (2.120-18.426), artinya responden yang tidak patuh mempunyai peluang sebesae 6,2 kali terhadap risiko terjadinya ulkus dibandingkan dengan responden yang patuh diet DM.

Hasil penelitian David di Texas menyatakan bahwa terdapat hubungan yang bermakna antara ketidakpatuhan diet dengan ulkus diabetika dengan odds ratio sebesar 16 (95\% CI : 8,3 - 21,6).

Kepatuhan diet DM mempunyai fungsi yang sangat penting yaitu mempertahankan berat badan normal, menurunkan tekanan darah sistolik dan diastolik, menurunkan kadar glukosa darah, memperbaiki profil lipid, meningkatkan sensitivitas reseptor insulin dan memperbaiki sistem koagulasi darah. Semakin bertambahnya tingkat kepatuhan diet DM maka semakin berkurang risiko terjadinya ulkus.

Hasil analisis diperoleh nilai OR : 5.333 (1.915 - 14.855), artinya responden yang tidak teratur menjalani pengobatan mempunyai peluang sebesar 5,3 kali terhadap risiko terjadinya ulkus diabetika dibandingkan dengan responden yang teratur menjalani pengobatan.

Penelitian ini sesuai dengan teori bahwa pengobatan rutin pada penderita Diabetes Mellitus tipe I, menurut hasil penelitian di Amerika Serikat didapatkan 
bahwa pengobatan intensif akan dapat mencegah dan menghambat timbulnya KESIMPULAN DAN SARAN

Ada hubungan umur dengan risiko terjadinya ulkus diabetika pada pasien Diabetes Mellitus di Poliklinik Endokrin Rumah Sakit Umum Daerah dr. Zainoel Abidin Banda Aceh p value $0,000(\mathrm{p}<0,05)$ Ada hubungan dukungan lama Diabetes Mellitus dengan risiko terjadinya ulkus diabetika pada pasien Diabetes Mellitus di Poliklinik Endokrin Rumah Sakit Umum Daerah dr. Zainoel Abidin Banda Aceh p value 0,000 ( $\mathrm{p}<$ 0,05). Ada hubungan kepatuhan diet DM dengan risiko terjadinya ulkus diabetika pada pasien Diabetes Mellitus di Poliklinik Endokrin Rumah Sakit Umum Daerah dr. Zainoel Abidin Banda Aceh $\mathrm{p}$ value 0,001 ( $>>0,05)$ Ada hubungan keteraturan pengobatan dengan risiko terjadinya ulkus diabetika pada pasien Diabetes Mellitus di Poliklinik Endokrin

\section{DAFTAR PUSTAKA}

1. Depkes, RI. (2007). Diabetes Mellitus merupakan masalah kesehatan yang serius, http : // www. depkes. go. Id / index. php.

2. Suyono, S. (1999). Masalah Diabetes di Indonesia. Dalam : Noer, dkk, editors, Ilmu Penyakit Dalam, Jilid I, Edisi ketiga, Penerbit FK UI, Jakarta.

3. Sitompul, Barita. (2011). Diabetes, dalam Ragam Berita \& Artikel Pusat Jantung Harapan Kita. Available at : www.pjnhk.go.id/berita_artikel/201 1/page/2/.

4. Amstrong, David G. (2011). Diabetic foot ulcers : Prevention, Diagnosis and Classification, avaible at : http//www.aafp.org/980315ap/arms tron, accessed.

5. Riyanto, B. 2010. Infeksi pada Kaki Diabetik. Dalam : Darmono, dkk, komplikasi kronik, seperti ulkus diabetika. ${ }^{[9]}$

Rumah Sakit Umum Daerah dr. Zainoel Abidin Banda Aceh p value 0,002 (p< $0,05)$.

Diharapkan kepada kepala poliklinik Endokrin RSUD dr. Zainoel Abidin Banda Aceh diharapkan dapat memberikan konseling tentang risiko terjadinya ulkus diabetika pada pasien Diabetes Mellitus. Kepada penderita, agar dapat lebih meningkatkan dalam hal pengalaman terkait tentang risiko terjadinya ulkus diabetika pada pasien Diabetes Mellitus, dan kepada peneliti selanjutnya diharapkan dapat melanjutkan penelitian ini secara lebih mendalam dengan menggunkan variabel-variabel lainnya yang juga merupakan faktor yang berhubungan dengan risiko terjadinya ulkus diabetika pada pasien Diabetes Mellitus.

editors. Badan Penerbit Universitas Diponegoro Semarang.

6. Rumah Sakit Umum Daerah dr. Zainoel Abidin. (2018). Gambaran Umum RSUD dr. Zainoel Abidin

7. Rochmah,W. (2006). Diabetes Mellitus Pada Usia Lanjut. Dalam : Aru W,dkk, editors, Ilmu Penyakit Dalam, Jilid III, Edisi keempat, Penerbit FK UI, Jakarta.

8. Waspadji, S. (2006). Komplikasi Kronik Daiabetes : Mekanisme Terjadinya, Diagnosis dan Strategi Pengelolaan. Dalam : Aru W, dkk, editors, Ilmu Penyakit Dalam, Jilid III, Edisi keempat, Penerbit FK UI, Jakarta.

9. Misnadiarly. 2006. Diabetes Mellitus : Ulcer, Infeksi, Ganggren. Penerbit Populer Obor, Jakarta. 


\section{LAMPIRAN}

Tabel [1]. Distribusi Frekuensi Responden $(n=93)$

\begin{tabular}{lllcc}
\hline \multicolumn{1}{c}{ Karakteristik } & & Kategori & Frekuensi & \% \\
\hline Jenis Kelamin & a. & Laki-laki & 42 & 45,2 \\
& b. & Perempuan & 51 & 54,8 \\
\hline Pendidikan & a. & SD & 11 & 11,8 \\
& b. & SMP & 33 & 35,5 \\
& c. & SMA & 34 & 36,6 \\
& d. & PT & 15 & 16,1 \\
\hline Pekerjaan & a. & Swasta & 58 & 62,4 \\
& b. & IRT & 18 & 19,4 \\
& c. & PNS & 17 & 18,3 \\
\hline \multicolumn{1}{c}{ Variabel } & & Kategori & Frekuensi & $\mathbf{\%}$ \\
\hline Status Ulkus & a. & Ulkus & 30 & 32,3 \\
& b. & Tidak Ulkus & 63 & 67,7 \\
\hline Umur & a. & $\geq 60$ tahun & 31 & 33,3 \\
& b. & $\leq 60$ tahun & 62 & 66,7 \\
\hline Lama Diabetes Mellitus & a. & $\geq 10$ tahun & 8 & 8,6 \\
& b. & $\leq 10$ tahun & 85 & 91,4 \\
\hline Kepatuhan Diet DM & a. & Tidak patuh & 53 & 57 \\
& b. & Patuh & 40 & 43 \\
\hline Keteraturan Pengobatan & a. & Tidak teratur & 51 & 54,8 \\
& b. & Teratur & 42 & 45,2 \\
\hline Total Responden & & & $\mathbf{9 3}$ & $\mathbf{1 0 0}$ \\
\hline
\end{tabular}

Sumber : Data Primer (Diolah 2018) 
Tabel [2]. Analisis Bivariat Terjadinya Ulkus Di Poliklinik Endokrin RSUD dr. Zainoel Abidin Banda Aceh Tahun 2018 ( $\mathrm{n}=93$ )

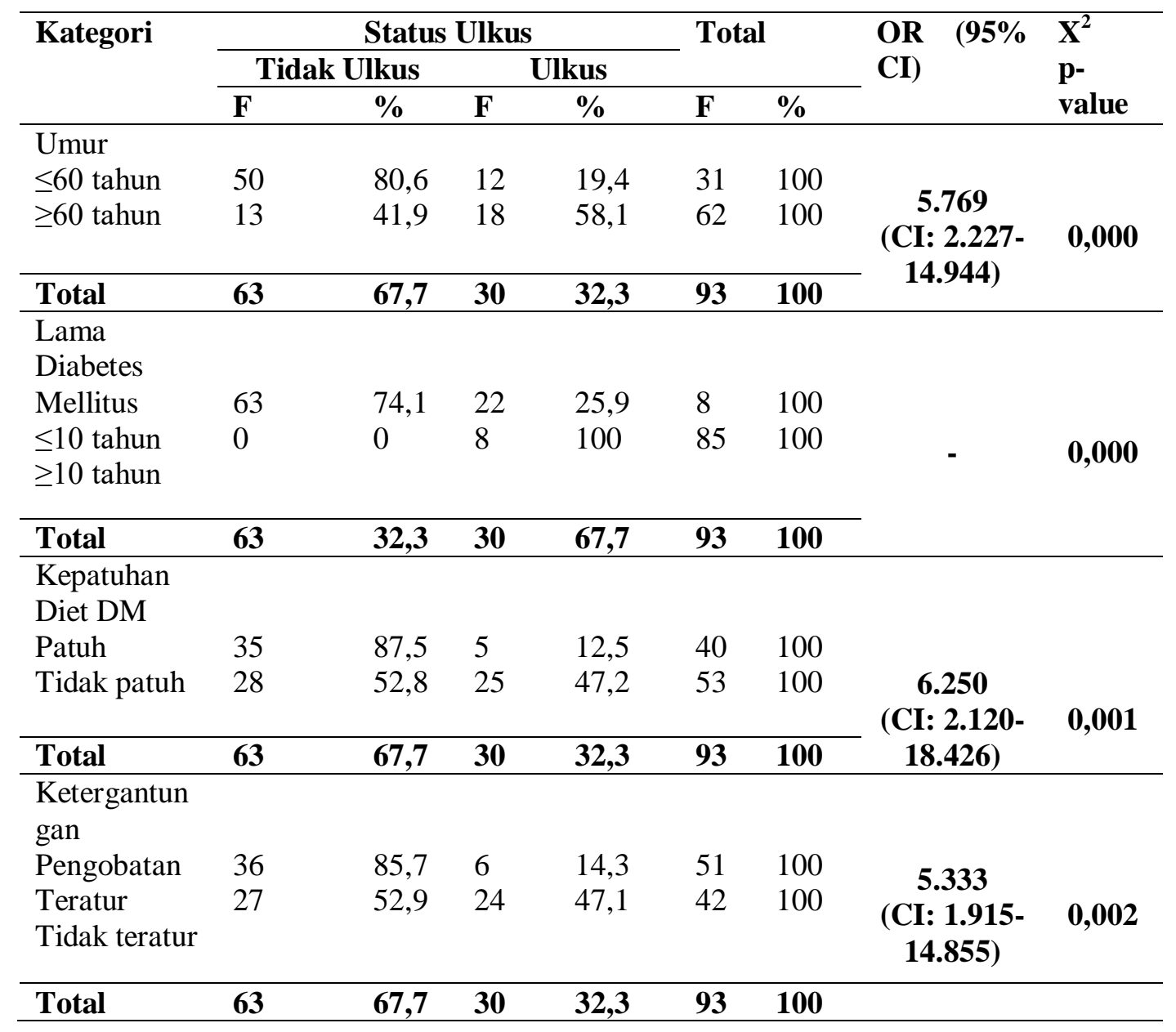

